Article

\title{
Exploring Common Culinary Herbs and Spices as Potential Anti-Quorum Sensing Agents
}

\author{
Sekelwa Cosa ${ }^{1}{ }^{10}$, Sushil Kumar Chaudhary ${ }^{1}\left({ }^{1}\right.$, Weiyang Chen ${ }^{1}$, Sandra Combrinck ${ }^{1,2}$ and \\ Alvaro Viljoen ${ }^{1,2, *}$ \\ 1 Department of Pharmaceutical Sciences, Tshwane University of Technology, Private Bag X680, \\ Pretoria 0001, South Africa; sekelwa.cosa@gmail.com (S.C.); sushpharma525@gmail.com (S.K.C.); \\ chenw@tut.ac.za (W.C.); combrincks@tut.ac.za (S.C.) \\ 2 SAMRC Herbal Drugs Research Unit, Tshwane University of Technology, Private Bag X680, \\ Pretoria 0001, South Africa \\ * Correspondence: viljoenam@tut.ac.za; Tel.: +27-12-382-6373
}

Received: 24 February 2019; Accepted: 21 March 2019; Published: 29 March 2019

\begin{abstract}
Quorum sensing controls bacterial pathogenesis and virulence; hence, interrupting this system renders pathogenic bacteria non-virulent, and presents a novel treatment for various bacterial infections. In the search for novel anti-quorum sensing (AQS) compounds, 14 common culinary herbs and spices were screened for potential antipathogenicity activity against Chromobacterium violaceum ATCC 12472. Extracts of Glycyrrhiza glabra (liquorice), Apium graveolens (celery), Capsicum annuum (cayenne pepper) and Syzygium anisatum (aniseed) demonstrated good AQS potential, yielding opaque halo zones ranging from $12-19 \mathrm{~mm}$ diameter at sub-minimum inhibitory concentrations $(0.350-4.00 \mathrm{mg} / \mathrm{mL})$. For the same species, the percentage reduction in violacein production ranged from 56.4 to $97.3 \%$. Zones with violacein inhibitory effects were evident in a celery extract analysed using high performance thin layer chromatography-bio-autography. The major active compound was isolated from celery using preparative-high performance liquid chromatography-mass spectrometry and identified using gas chromatography-mass spectrometry (GC-MS) as 3-n-butyl-4,5-dihydrophthalide (sedanenolide). Potent opaque zones of inhibition observed on the HPTLC-bio-autography plate seeded with C. violaceum confirmed that sedanenolide was probably largely responsible for the AQS activity of celery. The bacteriocidal properties of many herbs and spices are reported. This study, however, was focussed on AQS activity, and may serve as initial scientific validation for the anti-infective properties ascribed to several culinary herbs and spices.
\end{abstract}

Keywords: antimicrobial; anti-quorum sensing; Apium graveolens; HPTLC-bio-autography; LC-MS; 3-n-butyl-4,5-dihydrophthalide; sedanenolide

\section{Introduction}

Herbs and spices play a prominent role in the traditional culinary practices of many cultures and are an indispensable part of their daily diets. Culinary herbs and spices (in the form of leaves, roots, bark, berries, buds, seeds, stigmas or flowers) impart flavour, aroma and colour to dishes, and have been used for centuries for the preservation of food, including meats, sauces, vegetables, desserts, and in wine making $[1,2]$. Their main effects are to retard microbial growth and lipid oxidation during storage. Several herbs and spices, such as clove, cinnamon, oregano and rosemary, are reported to have significant antimicrobial [3], anti-oxidant [4,5] and/or anticarcinogenic activities. The literature reports a clear relationship between the anti-oxidant activity, antibacterial activity and total phenolic content of some herbs and spices $[2,6,7]$. However, non-phenolic compounds may also contribute 
to the antimicrobial effect of plants, for example 1'-acetoxychavicol acetate in galangal and allyl isothiocyanate in horseradish [8].

Although herbs and spices are minor ingredients of foods [9] and exhibit inferior activity when compared to antibiotic drugs, they have fewer side effects and are classified as "Generally Recognised As Safe" (GRAS) by the United States Food and Drug Administration (USFDA). Many of their bioactive compounds have been investigated extensively for the potential prevention and treatment of various diseases [10]. Beneficial human health-promoting properties include the treatment of toothache, fever, and pain (clove), nervous system conditions and stomach/intestinal infections (cinnamon), the use as an antiseptic and diuretic (mustard, garlic), application to accelerate wound healing (basil), and anticancer effects (turmeric) [11,12]. Some culinary herbs and spices possess anti-adhesive properties, meaning that they contain compounds that prevent the adhesion of microbes to the host tissue, thus preventing primary infection [11]. Although the biological activities of several culinary herbs and spices have been reported, their anti-quorum sensing (AQS) properties have remained unexplored.

Quorum sensing (QS) regulates some communal behaviours that involve significant phenomena such as bioluminescence, swarming, biofilm formation, motility, sporulation, antibiotic production and the expression of virulence factors, including the production of lytic enzymes, toxins, siderophores and adhesion molecules [13-15] in several bacteria. Virulence and pathogenicity in many clinically relevant bacterial pathogens are controlled by QS $[16,17]$. An approach based on obstructing microbial communication has emerged as an effective strategy to impede cooperative actions and reduce pressure on bacteria to develop resistance [18]. Compounds that interfere with the QS system to attenuate bacterial pathogenicity are termed anti-quorum sensing (AQS) compounds. Although such compounds do not kill bacteria, or inhibit their growth, bacteria are less likely to develop resistance towards them, in contrast to existing antibiotics $[19,20]$. Effective AQS agents are required to be chemically stable, exert negligible toxicity, and have a low molecular weight and a high degree of specificity for the signal receptor [15].

Hypothetically, it is reasonable to speculate that herbs and spices may contain QS-inhibiting phytochemicals, in view of the vast array of potentially bioactive secondary metabolites produced by plants. The objective of this study was therefore to investigate the potential of selected common culinary herbs and spices as AQS agents. Fourteen herbs and spices were screened for AQS activity against Chromobacterium violaceum, a Gram-negative bacterium, which produces a violacein pigment in response to QS-regulated gene expression. In C. violaceum, the production of violacein is regulated by genes arranged in an operon that is mediated by the acylhomoserine lactone (AHL) QS system [21]. The strain is generally accepted as a convenient model to assay for AQS agents.

\section{Materials and Methods}

\subsection{Plant Materials and Extraction}

Fourteen herbs and spices (Table 1), selected for anti-QS screening, were purchased from Warren Chemicals, South Africa. The specific plant part used as a herb or spice, for example, the root of horseradish, was obtained. Reference material has been retained in the Department of Pharmaceutical Sciences at Tshwane University of Technology. The criterion for choosing the plants was based on their traditional use associated with antimicrobial properties. Portions $(5.0 \mathrm{~g})$ of powdered herb material were individually extracted with solvents $(50.0 \mathrm{~mL}$ ) representing a range of polarities (water, methanol, ethyl acetate and dichloromethane), for $48 \mathrm{~h}$ at room temperature. The respective extracts were filtered using Whatman No. 1 filter paper. The residual material was returned for re-extraction, whereafter the combined corresponding crude extracts were air-dried in a fume hood for up to three days, depending on the extract, or freeze-dried (water extract) (SP Scientific freeze dryer USA) and the residues weighed. Stock solutions of each crude extract $(100 \mathrm{mg} / \mathrm{mL})$ were prepared using dimethyl sulfoxide (1\% DMSO; Merck, Johannesburg, South Africa) and further diluted to yield final concentrations ranging from 0.350 to $7.00 \mathrm{mg} / \mathrm{mL}$. The sterility of the extracts was verified by streaking them on Luria Bertani 
(LB) agar, followed by incubation at $37^{\circ} \mathrm{C}$ for $24 \mathrm{~h}$. The percentage yields of different extracts were calculated using the formula:

$$
\text { Percentage yield }(\%)=\frac{d r y \text { crude extract }}{\text { dry initial plant material before extraction }} \times 100
$$

Table 1. Herbs and spices selected for screening for anti-quorum sensing (AQS) potential.

\begin{tabular}{|c|c|c|c|c|}
\hline $\begin{array}{l}\text { Species } \\
\text { Name }\end{array}$ & Family Name & $\begin{array}{l}\text { Common } \\
\text { Name }\end{array}$ & Medicinal Use & Reference \\
\hline $\begin{array}{l}\text { Allium } \\
\text { sativum }\end{array}$ & Amaryllidaceae & Garlic & $\begin{array}{l}\text { Treatment of various disorders such as respiratory } \\
\text { ailments, asthma, pneumonia, diabetes, } \\
\text { cardiovascular disorders and rheumatism }\end{array}$ & {$[22,23]$} \\
\hline $\begin{array}{l}\text { Apium } \\
\text { graveolens }\end{array}$ & Apiaceae & Celery & $\begin{array}{l}\text { Treat toothache, diarrhea, hypertension } \\
\text { and-pulmonary disease. Used as stimulant, cardiac } \\
\text { tonic, carminative, diuretic and antiseptic }\end{array}$ & {$[24,25]$} \\
\hline $\begin{array}{l}\text { Armoracia } \\
\text { rusticana }\end{array}$ & Brassicaceae & Horse-radish & $\begin{array}{c}\text { Cough, lung and heart disease, diuretic, digestion, } \\
\text { wounds, shortness of breath, stomach problems, } \\
\text { bronchitis, headache, high blood pressure } \\
\text { and rheumatism }\end{array}$ & [26] \\
\hline $\begin{array}{l}\text { Capsicum } \\
\text { annuum }\end{array}$ & Solanaceae & $\begin{array}{l}\text { Cayenne } \\
\text { pepper }\end{array}$ & $\begin{array}{l}\text { Use in traditional medicine to alleviate gastric ulcers, } \\
\text { rheumatism, alopecia, toothache and diabetes }\end{array}$ & {$[27,28]$} \\
\hline $\begin{array}{l}\text { Cinnamomum } \\
\text { zeylanicum }\end{array}$ & Lauraceae & Cinnamon & $\begin{array}{c}\text { Benefit for common cold, cardiovascular, } \\
\text { neurodegenerative diseases and gastrointestinal } \\
\text { disorders }\end{array}$ & [4] \\
\hline Curcuma longa & Zingiberaceae & Turmeric & $\begin{array}{l}\text { Anti-inflammatory and for the treatment of jaundice, } \\
\text { menstrual difficulties, hematuria, hemorrhage, and } \\
\text { colic. Applied topically for urticaria and skin allergy, } \\
\text { viral hepatitis, inflammatory conditions of joints, } \\
\text { sore throat and wounds }\end{array}$ & [29] \\
\hline $\begin{array}{l}\text { Glycyrrhiza } \\
\text { glabra }\end{array}$ & Fabaceae & Liquorice & $\begin{array}{l}\text { Used in medicines for its unique and diverse } \\
\text { pharmacological properties viz., antiviral, anticancer, } \\
\text { anti-ulcer, anti-diabetic, anti-inflammatory, } \\
\text { anti-oxidant, immuno-stimulant, anti-allergenic }\end{array}$ & [30] \\
\hline $\begin{array}{l}\text { Melissa } \\
\text { officinalis }\end{array}$ & Lamiaceae & Lemon balm & Treat infections of Herpes simplex & [31] \\
\hline $\begin{array}{l}\text { Mentha } \\
\text { piperita }\end{array}$ & Lamiaceae & $\begin{array}{l}\text { Peppermint } \\
\text { (wild) }\end{array}$ & $\begin{array}{l}\text { Used to treat coughs, bronchitis, inflammation of } \\
\text { oral mucosa and throat, pulmonary tuberculosis, } \\
\text { digestive complaints such as colic in infants, } \\
\text { flatulence, diarrhea, indigestion, nausea, morning } \\
\text { sickness and anorexia }\end{array}$ & [32] \\
\hline $\begin{array}{l}\text { Rosmarinus } \\
\text { officinalis }\end{array}$ & Lamiaceae & Rosemary & $\begin{array}{c}\text { Relief pain in renal colic and dysmenorrhoea, and as } \\
\text { antispasmodic diuretic, antipyretic and as a } \\
\text { mood stabilizer }\end{array}$ & [33] \\
\hline $\begin{array}{l}\text { Syzygium } \\
\text { anisatum }\end{array}$ & Myrtaceae & Aniseed & Sedative and stimulant in cough medicines & [34] \\
\hline $\begin{array}{l}\text { Syzygium } \\
\text { aromaticum }\end{array}$ & Myrtaceae & Cloves & $\begin{array}{l}\text { Used to treat indigestion, flatulence, nausea, } \\
\text { vomiting, diarrhea, cough, infertility, warts, hernias, } \\
\text { ringworm, wounds, toothaches, athletes foot and } \\
\text { other fungal infections }\end{array}$ & [34-36] \\
\hline $\begin{array}{l}\text { Thymus } \\
\text { vulgaris }\end{array}$ & Lamiaceae & Thyme & $\begin{array}{c}\text { Bronchial asthma, inflammatory affection, } \\
\text { hepatotoxicity, atherosclerosis, ischaemic heart } \\
\text { disease, cataracts, cancer, insufficient sperm mobility }\end{array}$ & [37] \\
\hline $\begin{array}{l}\text { Zingiber } \\
\text { officinale }\end{array}$ & Zingiberaceae & Ginger & $\begin{array}{l}\text { Used for cold-induced diseases, nausea, asthma, } \\
\text { cough, colic, heart palpitation, swelling, dyspepsia, } \\
\text { less appetite and rheumatism }\end{array}$ & [38] \\
\hline
\end{tabular}




\subsection{Test Bacteria and Culture Media}

Biosensor strain Chromobacterium violaceum ATCC 12472, a wild-type strain producing a QS-controlled purple pigment, violacein, was used for the qualitative and quantitative determination of QS inhibition. An active bacterial culture was prepared in LB broth and agar (1\% tryptone, $0.5 \%$ yeast extract, $1 \% \mathrm{NaCl}$ and $1.5 \%$ agar) medium at $30{ }^{\circ} \mathrm{C}$ for $24 \mathrm{~h}$ with shaking. Cultures were maintained in LB agar at $4{ }^{\circ} \mathrm{C}$.

\subsection{Determination of the Antimicrobial Activities of Extracts}

Antimicrobial susceptibility of the 56 extracts was determined using the agar well diffusion method [39]. C. violaceum was grown on LB agar plates overnight at $30^{\circ} \mathrm{C}$, where after; the turbidity of the cell suspensions was adjusted using sterile deionised water, to a $0.5 \mathrm{McFarland}$ standard equivalent. These were used to inoculate Mueller-Hinton $(\mathrm{MH})$ agar plates by swabbing over the entire surface. After boring wells into the agar with a sterile $6 \mathrm{~mm}$ diameter cork borer, the wells were filled with $0.350,1.75,3.85$ and $7.00 \mathrm{mg} / \mathrm{mL}$ of each of the extracts, taking care to prevent spillage onto the surface of the agar medium. Plates were left on the laboratory bench to allow proper diffusion of the extract into the medium. After incubating the plates at $30{ }^{\circ} \mathrm{C}$ for $24 \mathrm{~h}$, the zones of inhibition were measured. Eugenol $(0.066 \mathrm{mg} / \mathrm{mL})$ and ciprofloxacin $(5 \mu \mathrm{g} / \mathrm{mL})$ were used as positive controls, while $1 \%$ DMSO was used as the negative control. The diameter of the inhibition zone was interpreted as follows: Susceptible $(S) \geq 15 \mathrm{~mm}$, Intermediate $(\mathrm{I})=11-14 \mathrm{~mm}$, and Resistant $(\mathrm{R}) \leq 10 \mathrm{~mm}$ as described by the Clinical and Laboratory Standards Institute [40].

\subsection{Determination of the Minimum Inhibitory Concentration}

The minimum inhibitory concentrations (MIC) of the crude extracts against C. violaceum were determined in triplicate in sterile, disposable flat-bottom 96-well microtitre plates, using the broth microdilution method as previously described [41]. Nutrient broth $(100 \mu \mathrm{L})$ was introduced into each of the 96 wells. Two-fold serial dilution of the plant extracts $(32 \mathrm{mg} / \mathrm{mL})$ was carried out by placing a $50 \mu \mathrm{L}$ portion of each test solution into a well in the first row, and after mixing, transferring a $50 \mu \mathrm{L}$ portion of each well content to the adjacent well in the next row, to yield nine test concentrations ranging from 8.00 to $0.0620 \mathrm{mg} / \mathrm{mL}$ for each solvent extract. Bacterial suspension $(50 \mu \mathrm{L})$ was subsequently added to each well. Ciprofloxacin $(5 \mu \mathrm{g} / \mathrm{mL})$ was used as the positive and 1\% DMSO as the negative control. The plates were incubated at $30^{\circ} \mathrm{C}$ for $18-24 \mathrm{~h}$. After the addition of $40 \mu \mathrm{L}$ of $0.2 \mathrm{mg} / \mathrm{mL}$ of $\rho$-iodonitrotetrazolium violet (INT; Merck, Johannesburg, South Africa) dissolved in sterile distilled water, to each well, they were left to stand at room temperature for $4 \mathrm{~h}$. The MIC was recorded as the lowest concentration of the extract that prevented the appearance of visible purple pigment growth of the organism after $24 \mathrm{~h}$ of incubation [42].

\subsection{Preliminary Screening of Anti-Quorum Sensing (AQS) Activity}

Chromobacterium violaceum was grown on LB agar. Thereafter, $5 \mathrm{~mL}$ of molten soft LB agar $(0.3 \% w / v)$ was inoculated with $50 \mu \mathrm{L}$ of $C$. violaceum, grown overnight in LB broth. The agar-culture mixture was immediately poured over the surface of pre-warmed LB agar plates as described [43]. After setting, wells were bored into the agar as before. For each extract, different concentrations $(0.35,1.75,3.85$ and $7.00 \mathrm{mg} / \mathrm{mL})$ of the extract solutions were pipetted into the agar wells. The plates were incubated overnight at $30^{\circ} \mathrm{C}$ and subsequently examined for violacein pigment production. Any AQS activity was evident by the formation of a colourless, opaque, but visible halo around the well, due to a loss of pigmentation. Eugenol $(0.066 \mathrm{mg} / \mathrm{mL})$ was used as the positive control, since it is a well-reported QS inhibitor. Dimethyl sulfoxide (1\% DMSO) was used as the negative control. 


\subsection{Quantitative AQS Activity}

Screening for AQS activity of the crude extracts was based on their ability to inhibit the production of the purple pigment violacein [44]. The strain was cultured aerobically in LB broth at $30{ }^{\circ} \mathrm{C}$, with or without the addition of increasing concentrations $(0.350-7.00 \mathrm{mg} / \mathrm{mL})$ of plant extract. A $1.00 \mathrm{~mL}$ portion of the overnight culture of the biosensor strain was centrifuged $(11,337 \times g, 10 \mathrm{~min})$ to precipitate the insoluble violacein. The culture supernatant was discarded and the pellet was evenly re-suspended in $1.00 \mathrm{~mL}$ of DMSO $(100 \%)$. The solution was again centrifuged $(11,337 \times g, 10 \mathrm{~min})$, to remove the cells, and the violacein was quantified by determining the optical density at $585 \mathrm{~nm}$ using a UV-Vis spectrophotometer. The percentage of violacein inhibition was calculated using the formula:

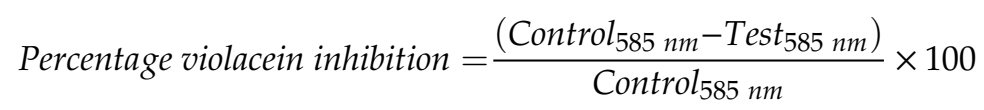

where Control represents the test bacteria without the presence of extract, and Test represents the bacteria exposed to the extract at various concentrations.

\subsection{Identification of Major Active Compounds and Their AQS Activity}

\subsubsection{High Performance Thin Layer Chromatography (HPTLC) Analysis}

Preliminary identification of the active components present in thirteen crude extracts with AQS activity, namely Apium graveolens (ethyl acetate and methanol), Armoracia rusticana (aqueous), Caspicum annum (dichloromethane), Glycyrrhiza glabra (aqueous and methanol), Melissa officinalis (aqueous), Rosmarinus officinales (ethyl acetate), Syzygium anisatum (ethyl acetate and dichloromethane); Syzygium aromaticum (methanol) and Thymus vulgaris (ethyl acetate and methanol) was achieved by using a CAMAG (Switzerland) semi-automated HPTLC system and the indirect bio-autography assay (as described in Section 2.7.2) [16,17], with some modifications. The active extracts $(3 \mu \mathrm{L}$ ) were spotted onto $\left(20 \times 10 \mathrm{~cm}\right.$ ) silica gel TLC plates (DC-Fertigfolien ALUGRAM1Xtra SIL G/UV ${ }_{254}$, Darmstadt, Germany) as $8 \mathrm{~mm}$ bands, $5 \mathrm{~mm}$ from the lower edge, using the automated TLC Sampler 4, fitted with a $25 \mu \mathrm{L}$ Hamilton microsyringe and connected to a nitrogen supply. Thereafter, the plates were developed using toluene:ethyl acetate:methanol:formic acid (7:6:1.5:1) in an ADC2 development chamber, consisting of a glass twin-trough chamber $(20 \mathrm{~cm} \times 10 \mathrm{~cm})$ with a metal lid. The developed plates were dried using the CAMAG TLC plate heater III. Two identical TLC plates were prepared: Plate 1 (not shown), the reference chromatogram was used to identify the presence of compounds, and determine their $R f$ values, when visualised under white light and UV irradiation (254 and $366 \mathrm{~nm}$ ), and Plate 2 used for bio-autography.

\subsubsection{HPTLC-Bio-Autography Assay}

Developed HPTLC plates (Plate 2), to which the 13 AQS-active extract had been applied, were placed face-up in a sterile Petri dishes and an inoculum of $C$. violaceum, standardized to $0.5 \mathrm{McF}$ arland standard equivalent in LB soft agar, was distributed evenly over the plates. After solidification of the medium, the Petri dishes were incubated at $30{ }^{\circ} \mathrm{C}$ for $24 \mathrm{~h}$. A purple-coloured background, reflecting violacein production and QS by the bacterium, was observed on the plate. In contrast, the presence of pale, turbid zones indicated the presence of compounds in the extracts responsible for AQS activity. The $R f$ values of the inhibition zones on the plate were compared with those determined from the reference chromatograms (Plate 1).

\subsubsection{Identification of the Target Compounds Using UHPLC-MS Analysis}

After assaying the crude extracts, the ethyl acetate extract of Apium graveolens was singled out for identification of the major active compounds responsible for AQS activity, since the HPTLC-bio-autography plate displayed a prominent active spot. The target compound was identified 
using ultra performance liquid chromatography-mass spectrometry (UHPLC-MS), and then isolated using preparative-high performance liquid chromatography-mass spectrometry (prep-HPLC-MS). The activity of the pure compound was confirmed using the HPTLC-bio-autography assay.

The UHPLC-QToF-MS analysis was conducted using a Waters Acquity Ultra Performance Liquid Chromatography system equipped with a photodiode array (PDA) detector (Waters, Milford, MA, USA). The injection volume was $3 \mu \mathrm{L}$. Separation of the compounds in the extract was achieved on an Acquity UHPLC BEH $C_{18}$ column $(150 \mathrm{~mm} \times 2.1 \mathrm{~mm}$, i.d., $1.7 \mu \mathrm{m}$ particle size, Waters $)$ maintained at $40{ }^{\circ} \mathrm{C}$. The mobile phase consisted of $0.1 \%$ formic acid in water (Solvent $\mathrm{A}$ ) and $100 \%$ acetonitrile (Romil Ltd, Cambridge, UK) (Solvent B) at a flow rate of $0.4 \mathrm{~mL} / \mathrm{min}$. Gradient elution was applied as follows: $5 \%$ B to $90 \%$ B within $15 \mathrm{~min}$, changed to $100 \%$ B over $3.5 \mathrm{~min}$, maintaining for $1 \mathrm{~min}$ and then returning to the initial ratio within $0.5 \mathrm{~min}$. Data were collected using MassLynx 4.1TM (Waters, Milford Massachusetts, MA, USA) chromatographic software. The UHPLC system was also interfaced with a Xevo G2QToF (Time-of-Flight) mass spectrometer. Both positive and negative ionisation modes were investigated, but the positive mode was selected since it yielded information-rich chromatograms. The desolvation temperature was set to $350{ }^{\circ} \mathrm{C}$ at a nitrogen flow rate of $500 \mathrm{~L} / \mathrm{h}$, and the source temperature was $100^{\circ} \mathrm{C}$. The capillary and cone voltages were set to 2900 and $45 \mathrm{~V}$, respectively. Data were collected over the range $\mathrm{m} / \mathrm{z} 100$ to 1000 .

\subsubsection{Isolation and Identification of the Active Compound}

A Waters Autopurification system, equipped with a Waters photodiode array (PDA) detector (Model 2998) and a QDa mass spectrometer (Waters, Milford, MA, USA), was used for targeted fractionation of the ethyl acetate extract of A. graveolens. The injection volume was $500 \mu \mathrm{L}$. Separation was achieved on an XBridge Prep C18 column ( $250 \times 19$ mm i.d., $5 \mu \mathrm{m}$ particle size, Waters) maintained at $40^{\circ} \mathrm{C}$. The mobile phase consisted of $0.1 \%$ formic acid in water (Solvent A) and acetonitrile (Solvent B) at a flow rate of $20 \mathrm{~mL} / \mathrm{min}$, Gradient elution was applied as follows: $5 \% \mathrm{~B}$, kept constant for $1 \mathrm{~min}$, increased to $40 \%$ B within $2 \mathrm{~min}$, changed to $90 \%$ B over $12 \mathrm{~min}$, and then to $95 \%$ B within $0.5 \mathrm{~min}$, maintaining for $0.5 \mathrm{~min}$, before returning to the initial ratio within $0.5 \mathrm{~min}$. The following MS conditions were used: positive ionisation mode, probe temperature $600^{\circ} \mathrm{C}$, source temperature $120^{\circ} \mathrm{C}$, capillary voltage $800 \mathrm{~V}$, cone voltages $10 \mathrm{~V}$. Data were collected by MassLynx 4.1 $1^{\mathrm{TM}}$ (Waters, Milford, MA, USA) chromatographic software over the range $\mathrm{m} / \mathrm{z} 100$ to 600 . Once isolated, the purity of the compound was determined using UHPLC-MS and UHPLC-photodiode array detection (PDA) and the activity was established using HPTLC-bio-autography against $C$. violaceum biomonitor strain.

The isolated compound, dissolved in hexane, was identified using an Agilent 7683B gas chromatograph (GC), coupled to a mass spectrometer (MS, Agilent 5973). The sample, dissolved in hexane, was analysed on a $60 \mathrm{~m}$ polyethylene glycol capillary column (HP-Innowax, $250 \mu \mathrm{m}$ diameter; $0.25 \mu \mathrm{m}$ film thickness). Electron impact ionization was applied, with the ionisation voltage set at $70 \mathrm{eV}$, and mass spectra were collected over the range $m / z$ 35-550. Three mass spectral libraries NIST, Flavor and Mass Finder 4 were used for comparison of the spectra.

\section{Results and Discussion}

\subsection{Crude Extract Yields}

The extractants methanol and water resulted in higher extraction yields than DCM and ethyl acetate (Table 2). Methanol extracted the highest mass from Mentha piperita (19.5\%) and Glycyrrhiza glabra (18.2\%). This was followed by water for Allium sativum, Capsicum annuum and Syzygium aromaticum with $19.1 \%, 13.9 \%$ and $13.2 \%$ extract yield, respectively. Both DCM and ethyl acetate extracted the least from Glycyrrhiza glabra (1.3\%), and Armoracia rusticana Allium sativum, Cinnamomum zeylanicum (1.7\%). 
Table 2. Crude extract yields $(\% w / w)$ obtained after extraction of herbs and spices with different solvents.

\begin{tabular}{ccccc}
\hline \multirow{2}{*}{ Plants } & \multicolumn{4}{c}{ Solvents } \\
\cline { 2 - 5 } & Aqueous & Methanol & DCM & Ethyl Acetate \\
\hline Allium sativum & $19.1 \%$ & $10.5 \%$ & $1.7 \%$ & $1.7 \%$ \\
Apium graveolens & $3.0 \%$ & $4.1 \%$ & $10.0 \%$ & $7.5 \%$ \\
Armoracia rusticana & $8.3 \%$ & $8.6 \%$ & $6.0 \%$ & $1.3 \%$ \\
Capsicum annuum & $13.9 \%$ & $6.4 \%$ & $6.7 \%$ & $3.3 \%$ \\
Cinnamomum zeylanicum & $4.0 \%$ & $3.3 \%$ & $3.1 \%$ & $1.7 \%$ \\
Curcuma longa & $3.3 \%$ & $7.5 \%$ & $2.8 \%$ & $2.2 \%$ \\
Glycyrrhiza glabra & $5.6 \%$ & $18.2 \%$ & $4.8 \%$ & $1.3 \%$ \\
Melissa officinalis & $8.3 \%$ & $11.1 \%$ & $6.6 \%$ & $10.8 \%$ \\
Mentha piperita & $10.8 \%$ & $19.5 \%$ & $1.7 \%$ & $4.3 \%$ \\
Rosmarinus officinalis & $8.2 \%$ & $10.6 \%$ & $8.4 \%$ & $6.0 \%$ \\
Syzygium anisatum & $10.1 \%$ & $4.8 \%$ & $5.4 \%$ & $5.3 \%$ \\
Syzygium aromaticum & $13.2 \%$ & $6.4 \%$ & $5.6 \%$ & $3.8 \%$ \\
Thymus vulgaris & $11.4 \%$ & $11.5 \%$ & $6.4 \%$ & $6.1 \%$ \\
Zingiber officinale & $7.0 \%$ & $6.4 \%$ & $3.3 \%$ & $5.8 \%$ \\
\hline
\end{tabular}

\subsection{Qualitative Evaluation of AQS Activity}

The C. violaceum biomonitor strain was used for preliminary qualitative screening of extracts for AQS activity. Halos were observed on lawns of the C. violaceum as a result of either (i) inhibition of cell growth, seen as a clear halo, or (ii) quenching of QS signals, observed as a turbid halo.

Varying degrees of bactericidal activity were observed (Table 3 ). The organism was susceptible to 12 of the 56 extracts tested, where the diameter of the clear inhibition zones were interpreted as follows: Susceptible (S) $\geq 15 \mathrm{~mm}$, Intermediate $(\mathrm{I})=11-14 \mathrm{~mm}$, and Resistant $(\mathrm{R}) \leq 10 \mathrm{~mm}$, as described by the Clinical and Laboratory Standards Institute [40]. Two of the aqueous, six of the methanol, two of the dichloromethane and two of the ethyl acetate extracts were highly active (zones $\geq 15 \mathrm{~mm}$ ), indicating that the active constituents represented a wide polarity range. The methanol extract of Glycyrrhiza glabra (liquorice) was highly active towards C. violaceum, yielding $15 \mathrm{~mm}$ inhibition zones at all concentrations tested, suggesting that further dilutions would still be active against the organism. A concentration-dependent inhibitory effect was observed for the dichloromethane extract of Cinnamomum zeylanicum (cinnamon), the methanol, dichloromethane extract and ethyl acetate extracts of Syzygium aromaticum (clove), the ethyl acetate extract of Armoracia rusticana (horseradish), and the aqueous extract of Melissa officinalis (lemon balm). Chromobacterium violaceum could be classified as susceptible to all these extracts, according to the zone diameters obtained, after exposure to the highest concentration $(7.00 \mathrm{mg} / \mathrm{mL})$. Furthermore, the organism displayed intermediate susceptibility towards most of the extracts over the range 7.00 to $0.350 \mathrm{mg} / \mathrm{mL}$, with the exception of Capsicum annuum (cayenne pepper; aqueous extract), Apium graveolens (celery, methanol and ethyl acetate extracts), Allium sativum (garlic, methanol extract), Melissa officinalis (lemon balm, dichloromethane extract) and Thymus vulgaris (thyme, ethyl acetate extract), for which complete resistance was observed. The antimicrobial data corroborate results obtained in previous studies. For example, an aqueous extract of Syzygium anisatum (aniseed) produced significant antibacterial activity against common pathogenic Gram-negative and Gram-positive bacteria [45]. Antimicrobial assays with plant extracts (acetone, DMSO and buffered methanol) obtained from Ruta graveolens (common rue) and Zingiber officinale (ginger) exhibited inhibitory activities against Bacillus cereus strains [46]. 
Table 3. Antibacterial activity of a range of concentrations of herbs and spices as determined using the agar well diffusion method.

\begin{tabular}{|c|c|c|c|c|c|c|c|c|c|c|c|c|c|c|c|c|}
\hline \multirow{4}{*}{ Plant Pecies } & \multicolumn{16}{|c|}{ Zone Diameters $(\mathrm{mm})$ and Associated Susceptibility Phenotypes } \\
\hline & \multicolumn{4}{|c|}{ Aqueous Extract } & \multicolumn{4}{|c|}{ Methanol Extract } & \multicolumn{4}{|c|}{ Dichloromethane Extract } & \multicolumn{4}{|c|}{ Ethyl Acetate Extract } \\
\hline & \multicolumn{16}{|c|}{ Concentration $(\mathrm{mg} / \mathrm{mL})$} \\
\hline & 0.350 & 1.75 & 3.85 & 7.00 & 0.350 & 1.75 & 3.85 & 7.00 & 0.350 & 1.75 & 3.85 & 7.00 & 0.350 & 1.75 & 3.85 & 7.00 \\
\hline Allium sativum & $11(\mathrm{I})$ & 11(I) & 12(I) & 13(I) & $10(\mathrm{R})$ & $10(\mathrm{R})$ & $10(\mathrm{R})$ & $10(\mathrm{R})$ & $11(\mathrm{I})$ & $12(\mathrm{I})$ & $12(\mathrm{I})$ & $12(\mathrm{I})$ & $11(\mathrm{I})$ & $11(\mathrm{I})$ & 12(I) & 12(I) \\
\hline Apium graveolens & $10(\mathrm{R})$ & $10(\mathrm{R})$ & $11(\mathrm{I})$ & $11(\mathrm{I})$ & $0(\mathrm{R})$ & $0(\mathrm{R})$ & $0(\mathrm{R})$ & $0(\mathrm{R})$ & $11(\mathrm{I})$ & $12(\mathrm{I})$ & $12(\mathrm{I})$ & $12(\mathrm{I})$ & $0(\mathrm{R})$ & $0(\mathrm{R})$ & $0(\mathrm{R})$ & $0(\mathrm{R})$ \\
\hline Armoracia rusticana & $0(\mathrm{R})$ & $10(\mathrm{R})$ & $11(\mathrm{I})$ & $11(\mathrm{I})$ & $12(\mathrm{I})$ & $11(\mathrm{I})$ & $11(\mathrm{I})$ & $11(\mathrm{I})$ & $12(\mathrm{I})$ & $13(\mathrm{I})$ & $13(\mathrm{I})$ & $12(\mathrm{I})$ & $10(\mathrm{R})$ & $11(\mathrm{I})$ & $12(\mathrm{I})$ & $14(\mathrm{~S})$ \\
\hline Capsicum annuum & $10(\mathrm{R})$ & $10(\mathrm{R})$ & $10(\mathrm{R})$ & $10(\mathrm{R})$ & 12(I) & $12(\mathrm{I})$ & 13(I) & $13(\mathrm{I})$ & $11(\mathrm{I})$ & $12(\mathrm{I})$ & 12(I) & $13(\mathrm{I})$ & $11(\mathrm{I})$ & $12(\mathrm{I})$ & $12(\mathrm{I})$ & 13(I) \\
\hline Cinnamomum zeylanicum & $11(\mathrm{I})$ & $12(\mathrm{I})$ & $11(\mathrm{I})$ & $11(\mathrm{I})$ & $11(\mathrm{I})$ & $11(\mathrm{I})$ & $12(\mathrm{I})$ & $12(\mathrm{I})$ & $11(\mathrm{I})$ & $12(\mathrm{I})$ & $12(\mathrm{I})$ & $14(\mathrm{~S})$ & $11(\mathrm{I})$ & $12(\mathrm{I})$ & $13(\mathrm{I})$ & 12(I) \\
\hline Curcuma longa & $10(\mathrm{R})$ & $11(\mathrm{I})$ & $12(\mathrm{I})$ & $12(\mathrm{I})$ & 10(R) & $11(\mathrm{I})$ & $12(\mathrm{I})$ & $12(\mathrm{I})$ & 10(R) & $11(\mathrm{I})$ & $12(\mathrm{I})$ & $12(\mathrm{I})$ & $10(\mathrm{R})$ & $11(\mathrm{I})$ & 12(I) & 12(I) \\
\hline Glycyrrhiza glabra & $10(\mathrm{R})$ & $11(\mathrm{I})$ & $12(\mathrm{I})$ & $13(\mathrm{I})$ & $15(\mathrm{~S})$ & $15(S)$ & 15(S) & $15(\mathrm{~S})$ & $10(\mathrm{R})$ & $10(\mathrm{R})$ & $10(\mathrm{R})$ & $11(\mathrm{I})$ & $13(\mathrm{I})$ & $13(\mathrm{I})$ & 13(I) & 13(I) \\
\hline Melissa officinalis & $11(\mathrm{I})$ & 12(I) & $15(S)$ & $15(\mathrm{~S})$ & $11(\mathrm{I})$ & $11(\mathrm{I})$ & $11(\mathrm{I})$ & $11(\mathrm{I})$ & $10(\mathrm{R})$ & $10(\mathrm{R})$ & $10(\mathrm{R})$ & $10(\mathrm{R})$ & $11(\mathrm{I})$ & $11(\mathrm{I})$ & 11(I) & 11(I) \\
\hline Mentha piperita & $11(\mathrm{I})$ & $12(\mathrm{I})$ & $12(\mathrm{I})$ & $12(\mathrm{I})$ & 10(R) & $11(\mathrm{I})$ & $12(\mathrm{I})$ & $12(\mathrm{I})$ & $11(\mathrm{I})$ & $12(\mathrm{I})$ & $12(\mathrm{I})$ & $12(\mathrm{I})$ & $11(\mathrm{I})$ & $12(\mathrm{I})$ & $12(\mathrm{I})$ & 12(I) \\
\hline Rosmarinus officinalis & $10(\mathrm{R})$ & $11(\mathrm{I})$ & $11(\mathrm{I})$ & $12(\mathrm{I})$ & $11(\mathrm{I})$ & $11(\mathrm{I})$ & $13(\mathrm{I})$ & $13(\mathrm{I})$ & $11(\mathrm{I})$ & $11(\mathrm{I})$ & $13(\mathrm{I})$ & $13(\mathrm{I})$ & $11(\mathrm{I})$ & $11(\mathrm{I})$ & $10(\mathrm{R})$ & $10(\mathrm{R})$ \\
\hline Syzygium anisatum & $12(\mathrm{I})$ & $13(\mathrm{I})$ & $13(\mathrm{I})$ & $12(\mathrm{I})$ & $11(\mathrm{I})$ & $12(\mathrm{I})$ & $13(\mathrm{I})$ & $16(S)$ & $11(\mathrm{I})$ & $11(\mathrm{I})$ & $13(\mathrm{I})$ & $14(S)$ & $11(\mathrm{I})$ & $11(\mathrm{I})$ & $11(\mathrm{I})$ & $14(\mathrm{~S})$ \\
\hline Syzygium anisatum & $11(\mathrm{I})$ & $12(\mathrm{I})$ & $12(\mathrm{I})$ & $12(\mathrm{I})$ & 11(I) & $12(\mathrm{I})$ & $11(\mathrm{I})$ & $11(\mathrm{I})$ & $0(\mathrm{R})$ & $11(\mathrm{I})$ & $11(\mathrm{I})$ & $11(\mathrm{I})$ & $12(\mathrm{I})$ & $12(\mathrm{I})$ & $12(\mathrm{I})$ & 12(I) \\
\hline Thymus vulgaris & $10(\mathrm{R})$ & $10(\mathrm{R})$ & $12(\mathrm{I})$ & $13(\mathrm{I})$ & $10(\mathrm{R})$ & $10(\mathrm{R})$ & $10(\mathrm{R})$ & $12(\mathrm{I})$ & $11(\mathrm{I})$ & $11(\mathrm{I})$ & $11(\mathrm{I})$ & $11(\mathrm{I})$ & $10(\mathrm{R})$ & $10(\mathrm{R})$ & $10(\mathrm{R})$ & $10(\mathrm{R})$ \\
\hline Zingiber officinale & $11(\mathrm{I})$ & $12(\mathrm{I})$ & $13(\mathrm{I})$ & $13(\mathrm{I})$ & $12(\mathrm{I})$ & $12(\mathrm{I})$ & $12(\mathrm{I})$ & $14(\mathrm{~S})$ & $12(\mathrm{I})$ & $13(\mathrm{I})$ & $13(\mathrm{I})$ & $13(\mathrm{I})$ & $12(\mathrm{I})$ & $13(\mathrm{I})$ & $13(\mathrm{I})$ & 13(I) \\
\hline CIP5 \# & \multicolumn{4}{|c|}{$31(\mathrm{~S})$} & \multicolumn{4}{|c|}{$30(S)$} & \multicolumn{4}{|c|}{$30(S)$} & \multicolumn{4}{|c|}{$30(S)$} \\
\hline Eugenol & \multicolumn{4}{|c|}{ 12(I) } & \multicolumn{4}{|c|}{$22(S)$} & \multicolumn{4}{|c|}{$24(S)$} & \multicolumn{4}{|c|}{$28(S)$} \\
\hline
\end{tabular}

CIP5" : ciprofloxacin $(5 \mu \mathrm{g} / \mathrm{mL})$. R, I and S denote Resistant, Intermediate Susceptibility and Susceptible. 


\subsection{Determination of MICs}

The MICs determined for aqueous, methanol, dichloromethane and ethyl acetate extracts of the various herbs and spices against C. violaceum ranged from 2.00 to $4.00 \mathrm{mg} / \mathrm{mL}$ (Table 4). None of the results indicated noteworthy activity, which is regarded as MIC values $<1 \mathrm{mg} / \mathrm{mL}$ [47]. Syzygium anisatum (aniseed), Syzygium aromaticum (clove), Glycyrrhiza glabra (liquorice), Melissa officinalis (lemon balm) and Thymus vulgaris (thyme) extracts inhibited the growth of $C$. violaceum with MICs of $2.00 \mathrm{mg} / \mathrm{mL}$ for all four extracts, but this activity is not regarded as noteworthy (Table 4).

Table 4. Minimum inhibitory concentrations (MICs) $(\mathrm{mg} / \mathrm{mL}$ ) determined using the broth microdilution method, and anti-QS activities using the agar well diffusion method of solvent extracts of various herbs and spices.

\begin{tabular}{|c|c|c|c|c|c|c|}
\hline \multirow{2}{*}{ Plants } & \multicolumn{4}{|c|}{ MIC (mg/mL) against CV12472 } & \multicolumn{2}{|c|}{ Anti-QS Activities } \\
\hline & Aqueous & Methanol & DCM & $\begin{array}{c}\text { Ethyl } \\
\text { Acetate }\end{array}$ & Active Plant Extract & $\begin{array}{l}\text { AQS Zone of } \\
\text { Inhibition ( } \mathrm{mm})\end{array}$ \\
\hline Allium sativum & 4 & 4 & 4 & 4 & NA & NA \\
\hline Apium graveolens & 4 & 4 & 4 & 4 & ethyl acetate; methanol & $14 ; 12-15$ \\
\hline Capsicum annuum & 4 & 4 & 4 & 4 & DCM & $13-14$ \\
\hline Cinnamomum zeylanicum & 4 & 2 & 2 & 2 & NA & NA \\
\hline Curcuma longa & 4 & 2 & 2 & 2 & NA & NA \\
\hline Glycyrrhiza glabra & 2 & 2 & 2 & 2 & aqueous; methanol & $19 ; 12$ \\
\hline Melissa officinalis & 2 & 2 & 2 & 2 & methanol & 9 \\
\hline Mentha piperita & 4 & 4 & 4 & 4 & NA & NA \\
\hline Thymus vulgaris & 2 & 2 & 2 & 2 & ethyl acetate; methanol & $13 ; 12$ \\
\hline Zingiber officinale & 4 & 2 & 2 & 2 & NA & NA \\
\hline
\end{tabular}

$\mathrm{DCM}=$ dichloromethane; $\mathrm{NA}=$ not active.

When the antipathogenic potential of the plant extracts were evaluated, fading of the violet-colour of the violacein pigment in the area surrounding the wells indicated their possible AQS effect. Qualitative screening of AQS activity indicated that 13 of the tested plant extracts displayed the ability to interfere with, or inhibit violacein pigment production, as observed by opaque halo formation present immediately against the clear zone of dead bacteria (Figure S1A). Bacteria in these opaque zones were viable, but unable to secrete violacein, which is a reflection of a loss of QS ability. The aqueous extract of Glycyrrhiza glabra (liquorice) yielded the largest AQS inhibition zone (19 $\mathrm{mm}$ ) (Table 4). Although the corresponding methanol extract exhibited a moderate MIC $(2.00 \mathrm{mg} / \mathrm{mL})$, it yielded a smaller AQS zone of inhibition (12 mm diameter) than the aqueous extract. The ethyl acetate $(14 \mathrm{~mm})$ and methanol (12-15 mm) extracts of Apium graveolens (celery) displayed similar AQS activity, but these extracts yielded MICs of $4.00 \mathrm{mg} / \mathrm{mL}$ (Table 4), reflecting poor bactericidal activity. This finding suggests that celery may be a good candidate for the isolation of active compounds with strong AQS, rather than strong bacteriocidal activity. Melissa officinalis (lemon balm, methanol extract) $(9 \mathrm{~mm})$ was the least active of those displaying AQS activity (Table 4). Most reported AQS agents demonstrate bactericidal effects, which often lead to AQS compounds being classified as antibacterial. However, in some cases compounds of natural origin yield poor MICs, yet have the ability to interfere with the QS-signalling mechanism at sub-MIC concentrations [21]. Packiavathy et al. [48] reported on the AQS ability of Capparis spinosa methanolic extract at $2 \mathrm{mg} / \mathrm{mL}$, while Chenia [49] reported that the hexane, ethyl acetate and dichloromethane extracts of Kigellia africana displayed good AQS activity at $1.31 \mathrm{mg} / \mathrm{mL}, 1.97 \mathrm{mg} / \mathrm{mL}$ and $3.93 \mathrm{mg} / \mathrm{mL}$, respectively. 


\subsection{Quantitative Evaluation of AQS Activity}

To further validate the results obtained through the qualitative assay, all the extracts were evaluated in a quantitative AQS activity assay by extraction of violacein, following exposure of $C$. violaceum to the test substances. This was also done to confirm that the inhibition of violacein production was not due to a bactericidal effect. Varying levels of inhibition were observed with the four solvent extracts, most frequently in a dose-dependent manner, with most inhibitory effects $(\geq 90 \%)$ recorded at the highest concentration $(7.00 \mathrm{mg} / \mathrm{mL})$. A sample displaying varying levels of inhibition after exposure to different extracts at $0.700 \mathrm{mg} / \mathrm{mL}$ is illustrated in Figure S1B. Eleven of the extracts were able to inhibit violacein production by more than $90 \%$ when applied at a concentration of $7.00 \mathrm{mg} / \mathrm{mL}$, with the best performers identified as Glycyrrhiza glabra (liquorice, methanol extract, 97.3\%), Armoracia rusticana (horseradish, aqueous extract, 97.2\%), and Rosmarinus officinalis (rosemary, dichloromethane extract, 96.7\%) (Table S1; Figure 1).

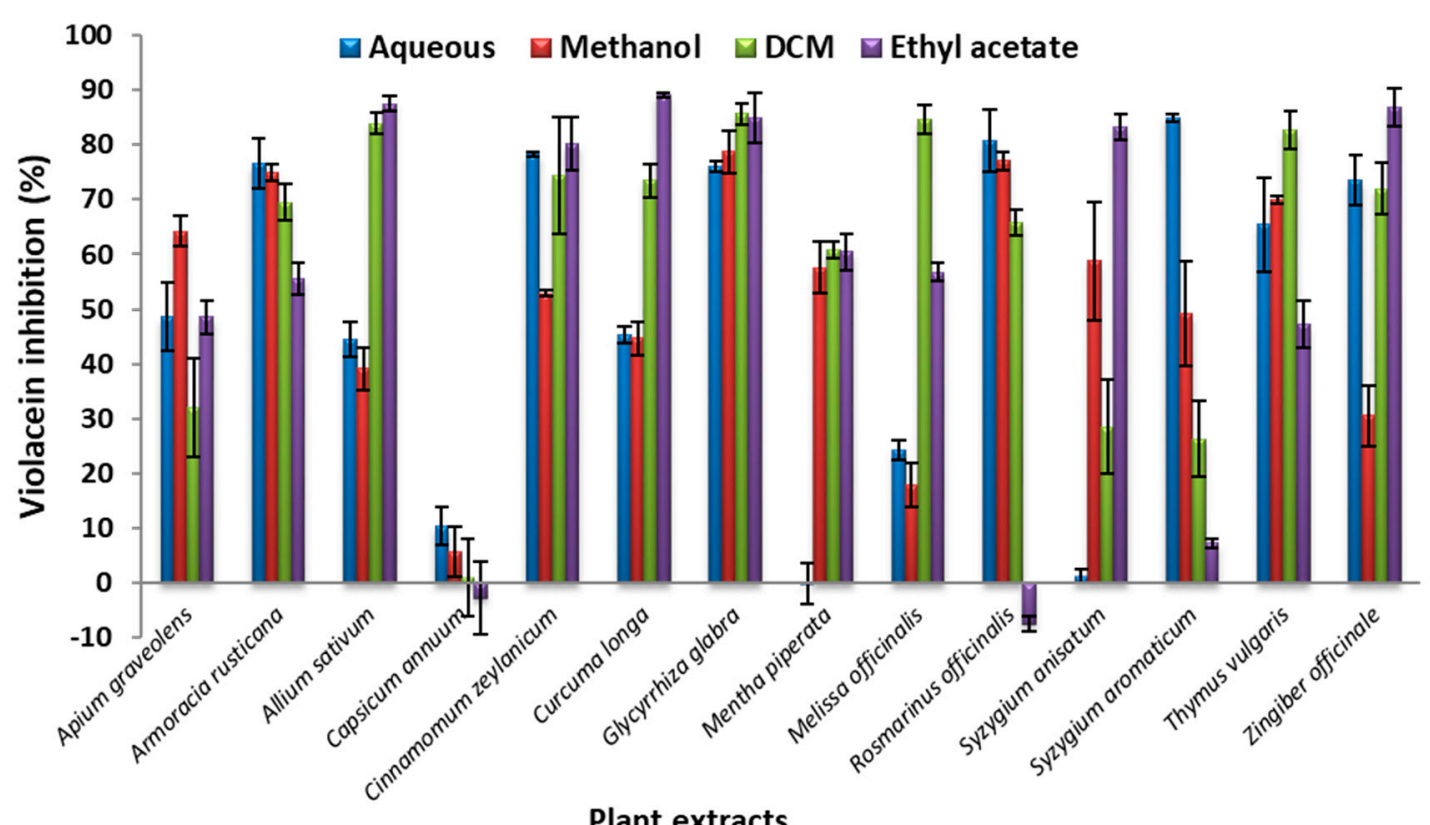

Figure 1. Percentage inhibition of violacein production after exposure of Chromobacterium violaceum to solvent extracts $(0.7 \mathrm{mg} / \mathrm{mL})$ of herbs and spice. Data presented as mean \pm standard deviation (SD). Further percentage violacein inhibition results for plant extracts over a range of concentrations are provided as Supplementary data (Table S1).

All four extracts of Glycyrrhiza glabra and Melissa officinalis (lemon balm), and three out of four extracts of Mentha piperita (mint), Syzgium anisatum (aniseed) and Zingiber officinale (ginger) inhibited the QS of C. violacein by more than $80 \%$. Higher AQS activity was obtained for Glycyrrhiza glabra, Armoracia rusticana, Rosmarinus officinalis, Thymus vulgaris, Curcuma longa (turmeric), and Melissa officinalis in the quantitative violacein inhibition assay as compared to the qualitative assay. Only Glycyrrhiza glabra (aqueous and methanol extracts), Armoracia rusticana (aqueous extract), Rosmarinus officinalis (ethyl acetate extracts), Thymus vulgaris (methanol and ethyl acetate extracts), and Melissa officinalis (methanol extract) displayed potential AQS activity in the qualitative assay. However, almost all of the extracts exhibited some degree of AQS activity. Curcuma longa displayed no AQS activity when it was determined using the qualitative assay; however, more than $80 \%$ activity was observed for the ethyl acetate extract in the quantitative assay. This suggests that the qualitative agar well diffusion assay may not be an appropriate technique to judge AQS activity. A quantitative assay should be accepted as the standard to eliminate the discrepancy between the two methods. 
It is noteworthy that, in many cases, dilution of the extracts to the lowest concentration $(0.35 \mathrm{mg} / \mathrm{mL})$ did not reduce the AQS activity in a dose-dependent manner. Dilution of Glycyrrhiza glabra and Melissa officinalis still yielded more than $74 \%$ inhibition of QS for all four extracts. The quorum sensing inhibitory effects of the aqueous extract of Cinnamonum zeylanicum and the ethyl acetate extract of Curcuma longa remained similar over the concentration range $0.350-7.00 \mathrm{mg} / \mathrm{mL}$. Since the positive solvent controls and negative controls did not reveal any method inconsistencies, the reason for this result remains unclear. The best values were achieved for the aqueous $(87.1 \pm 7.3 \%)$ and dichloromethane $(85.2 \pm 3.5 \%)$ extracts of the two plants at $0.350 \mathrm{mg} / \mathrm{mL}$, respectively. A similar pattern was established for the aqueous extract of Rosmarinus officinalis $(82.2 \pm 2.4 \%)$. The ethyl acetate extract $(85.8 \pm 2.4 \%)$ of Circuma longa also retained good activity when tested at the lowest concentration.

Based on a literature search, no mention is made of the AQS potential of Glycyrrhiza glabra and Melissa officinalis. Glycyrrhiza species are ancient herbal medicines that are used worldwide and are known for their antimicrobial properties, due to the presence of triterpenoid saponins [50]. Armoracia rusticana produces allyl isothiocyanate, which was reported to be bactericidal towards antibiotic-resistant bacteria [51]. However, the reported AQS activity was attributed to another compound, identified as iberin, which completely inhibited the expression of las $B$, without affecting bacterial growth in the Pseudomonas aeruginosa screen [52].

The results obtained in the current study indicate high AQS activity at sub-lethal concentrations as compared to other screenings based on ethnobotany. Several reports have documented the AQS activity of plant extracts against Chromobacterium violaceum. As an example, Vanilla planifolia (vanilla) has been reported to effectively inhibit the QS of C. violaceum [53]. The AQS activity of several fruit and spice extracts was attributed to interference with the AHL activity [54]. Raspberry, blueberry and grape extracts inhibited QS by $60 \%, 42 \%$ and $20 \%$, respectively. Other herbs and spices were found to be more effective in reducing the AHL activity-mediated inhibition of violacein production (CV026), with basil (78\%), thyme (60\%) and Brassica oleracea (60\%) being the most active, followed by rosemary, ginger and turmeric (40\%) [54]. The methanolic extract of Syzygium aromaticum (clove) reportedly caused a strong inhibition of $C$. violaceum $\mathrm{CV} 026$ responding to AHL, thus inhibiting its violacein production [55]. Fifty medicinal plants were screened for their anti-pathogenic properties, of which only six of the plant extracts (Conocarpus erectus, Chamaecyce, hypericifolia, Callistemon viminalis, Bucida burceras, Tetrazygia bicolor and Quercus virginiana) demonstrated good AQS activities [56]. It was also reported [39] that Apium graveolens, Thymus vulgaris and Rosmarinus officinalis essential oils had no AQS activity. However, essential oils of Syzygium aromaticum, Cinnamomum verum and Mentha piperita displayed good AQS activity against CV12472 and CV026 in the presence of $\mathrm{C}_{6}$-AHL [39].

\subsection{Identification and Isolation of Secondary Metabolites in Celery}

Amongst the plant extracts tested, Apium graviolens ethyl acetate extract produced only turbid halos attributed to QS signal molecule quenching, with no effect on bacterial cell growth. This observation, together with paucity in the published literature on the AQS properties of celery, prompted a more in-depth investigation of the chemistry of Apium graveolens using bio-autography as a guide to identify compounds with AQS activity.

The UHPLC-MS profile of the ethyl acetate crude extract revealed seven compounds, which were identified as (a) 3-butylidene-1(3H)-isobenzofuranone [56]; (b) 3-n-butylidene-phthalide [57]; (c) sedanenolide [57]; (d) (-)-2,3-dihydro-9-O- $\beta$-D-glucosyloxy-2-isopropenyl-7H-furo[3,2a][1]-benzopyran-7-one [58]; (e) isofraxidin-7-glucoside [59] and sedanenolide (3-n-butyl-4,5-dihydrophthalide), after comparison of their spectral data with data reported in literature (Figure 2). Phthalide compounds have a broad distribution and are prevalent in Apium graveolens. As example, Tang et al. [57] documented two major phthalide compounds, namely 3-n-butylphthalide (sedanolide) and 3- $n$-butyl-4,5-dihydrophthalide (sedanenolide) in Apium graveolens oil. These butylphthalides have been recognised for their physiological activities including anti-inflammatory, anti-carcinogenic and insecticidal effects [60]. 
In the present study, only sedanenolide was successfully isolated from Apium graveolens extract using prep-HPLC-MS, which enables the targeted isolation of a selected ion. The purity $(97 \%)$ of the compound was determined using UHPLC-MS and UHPLC-PDA (Figure 3), while the identity was confirmed as sedanenolide using GC-MS. When the compound was subjected to a HPTLC-bio-autography assay, AQS potential was observed as indicated by the zones evident in Figure 3. The AQS activity of sedanenolide probably involves the inhibition of the QS-related factor of C. violaceum, due to its structural similarity to the AHL class of QS-signal molecules. The mechanism of inhibition includes the compound competing and interfering with the activity of the signal molecules, due to their structural similarity. By binding to cviR, which encodes the enzyme for N-hexanoyl-L-homoserine lactone (C6-HSL) homologues, a rapid turnover of these proteins or alteration to their synthesis occurs, by promoting the degradation of CviR receptor proteins that bind the signal molecules [61]. By so doing, deleted or inactivated cviI interferes with, and reduces, QS-controlled violacein production by C. violaceum (12472). Several natural compounds have been demonstrated to behave as antagonists. These include halogenated acyl-furanones, which are structurally similar to AHLs, and were derived from the marine alga Delisea pulchra [62]. These compounds displace the 3-oxo-C6-HSL signal from its cognate LuxR receptor protein, thereby inhibiting the QS-mediated gene expression.

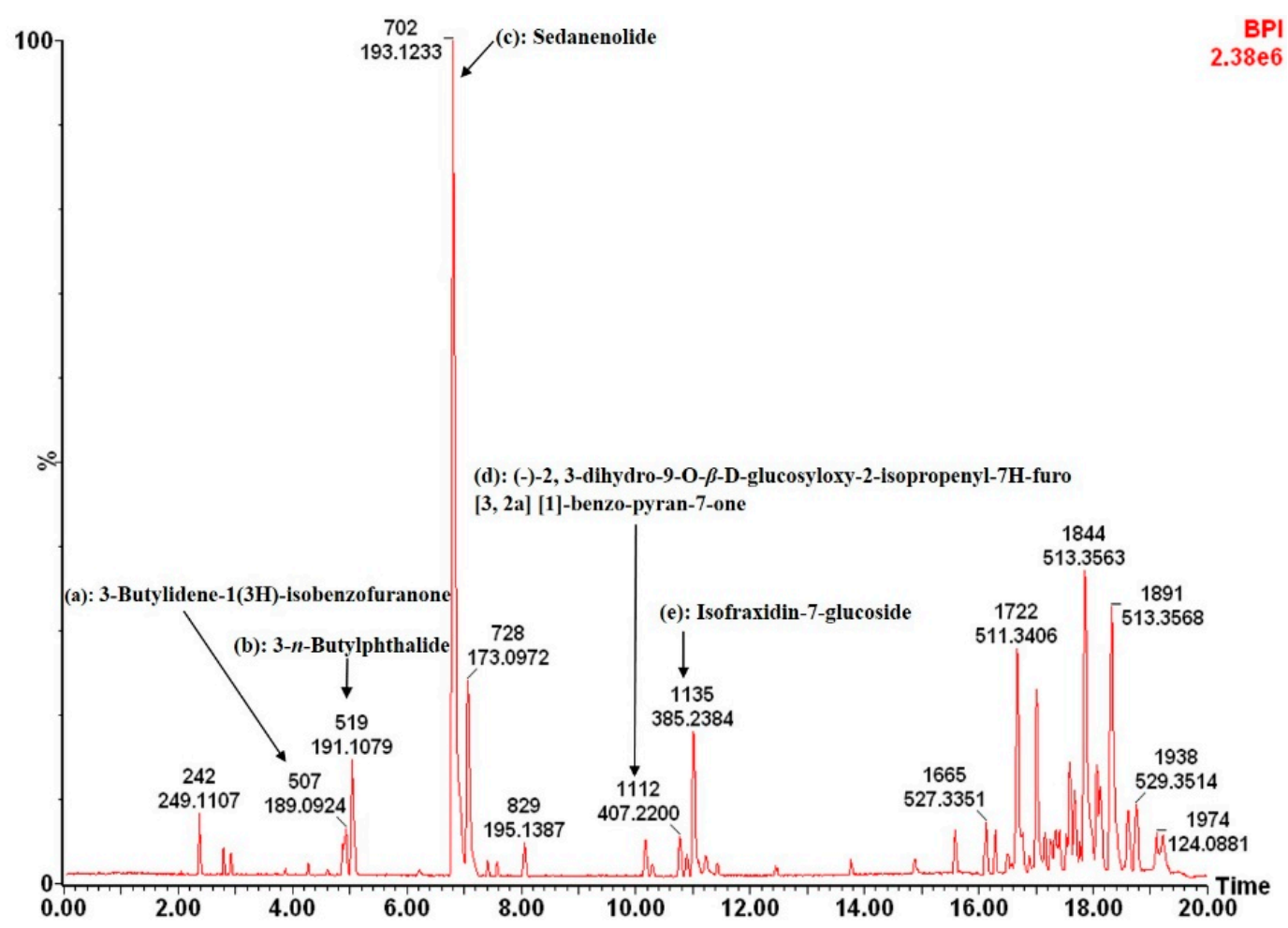

Figure 2. Ultra performance liquid chromatography-mass spectrometry (UHPLC-MS) chromatogram of the ethyl acetate crude extract of Apium graveolens indicating the presence of compounds identified using mass spectral data corresponding to positive mode. 


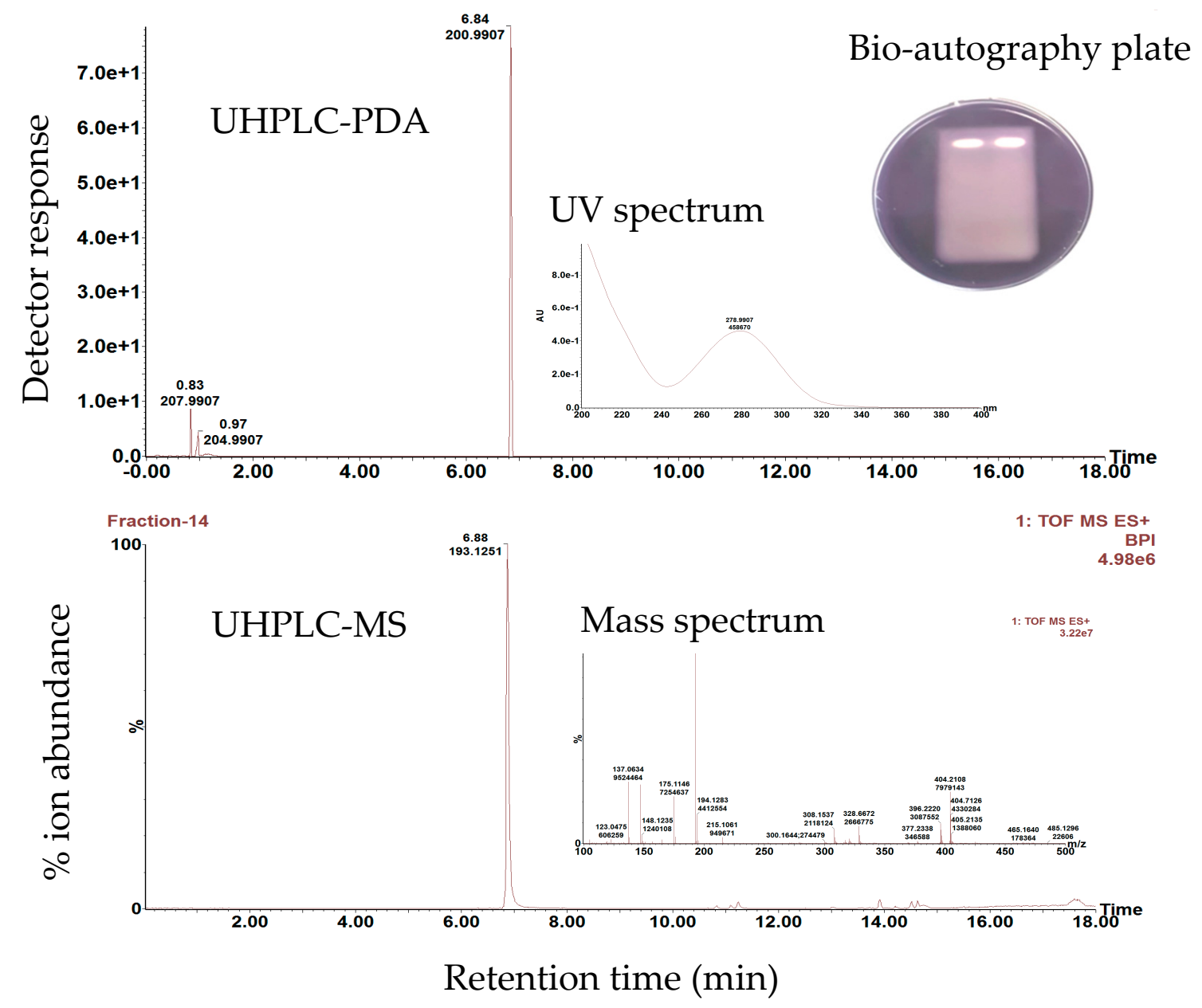

Figure 3. Ultra performance liquid chromatography (UHPLC)-photodiode array (PDA) and UHPLC-mass spectrometry (MS) chromatograms of sedanenolide, isolated from the ethyl acetate crude extract of Apium graveolens. The ultraviolet absorbance spectrum and mass spectrum are also provided. The high performance thin layer chromatography (HPTLC)-bio-autography plate of pure sedanenolide (in duplicate) against Chromobacterium violaceum is also indicated with the white zones confirming the anti-quorum sensing activity of the compound.

\section{Conclusions}

In this study, a better understanding of the health impact of herbs and spices was gained by investigating their AQS potential. Of the 56 plant extracts screened, several displayed both antimicrobial and AQS activities. All 14 herbs and spices assessed have potential to serve as either antimicrobial or antipathogenic agents. The quantitative AQS assay should be considered as a standard technique for screening botanicals for AQS agents. Based on the quantitative violacein inhibition, almost all extracts of different polarities displayed potential AQS activity, with the exception of Syzgium anisatum (ethyl acetate) and Zingiber officinale (methanol) extract, which caused less than $40 \%$ inhibition. The ethyl acetate extract of Apium graveolens was selected as the subject for further study since it demonstrated poor bactericidal activity towards C. violaceum, but inhibited the production of violacein by the bacterium. The extract and active compounds of celery have the potential to serve in the development of antipathogenic drugs and contribute to combating bacterial diseases, without adding to the burden of antibiotic resistance. Celery will have a greater advantage than any other botanicals for human use since it has been used safely for a long time and is edible. This study substantiates the potential of dietary phytochemicals as a source of anti-pathogenic compounds and highlights the importance of investigating understudied plants, rather than the traditional medicinal plants. Culinary herbs and spices present exciting opportunities for health promotion by contributing 
anti-oxidant, antimicrobial, pharmaceutical and nutritional properties. This study has contributed valuable information on the AQS properties of common culinary herbs and spices, to further the development of next-generation antipathogenic or antivirulence agents involved in inactivating signalling molecules that control pathogenicity.

Supplementary Materials: The following are available online at http://www.mdpi.com/2072-6643/11/4/739/s1, Table S1: Quantification of quorum sensing inhibitory effect of different plant extracts on violacein production at different concentrations $(0.350-7.00 \mathrm{mg} / \mathrm{mL})$, Figure S1: Representation of the agar well diffusion assay used to screen various plant extracts against Chromobacterium violaceum ATCC 12472.

Author Contributions: Conceptualization, A.V. and S.C. (Sekelwa Cosa); methodology, S.C. (Sekelwa Cosa), S.K.C., formal analysis, S.C. (Sekelwa Cosa), S.K.C. and W.C.; investigation, S.C. (Sekelwa Cosa) and S.K.C.; writing-original draft preparation, S.C. (Sandra Combrinck); writing-review and editing, A.V.; funding acquisition, A.V.

Funding: This research was funded by the National Research Foundation of South Africa (NRF/DST SARChI programme), the South African Medical Research Council and Tshwane University of Technology.

Conflicts of Interest: The authors declare no conflict of interest. The funders had no role in the design of the study; in the collection, analyses, or interpretation of data; in the writing of the manuscript, or in the decision to publish the results.

\section{Abbreviations}

The following abbreviations were used in this manuscript:

$\begin{array}{ll}\text { AHL } & \text { acylhomoserine lactone } \\ \text { AQS } & \text { anti-quorum sensing } \\ \text { ATCC } & \text { American Type Culture Collection } \\ \text { DCM } & \text { Dichloromethane } \\ \text { DMSO } & \text { dimethyl sulfoxide } \\ \text { GRAS } & \text { Generally Regarded As Safe } \\ \text { HPTLC } & \text { high performance thin layer chromatography } \\ \text { I } & \text { Intermediate } \\ \text { INT } & \text { p-iodonitrotetrazolium violet } \\ \text { LB } & \text { Luria Bertani } \\ \text { LC-MS } & \text { liquid chromatography-mass spectrometry } \\ \text { MIC } & \text { minimum inhibitory concentration } \\ \text { NA } & \text { not active } \\ \text { PDA } & \text { photodiode array } \\ \text { prep-HPLC-MS } & \text { preparative high performance liquid chromatography-mass spectrometry } \\ \text { QS } & \text { quorum sensing } \\ \text { R } & \text { Resistant } \\ \text { Rf } & \text { retardation factor } \\ \text { S } & \text { Susceptible } \\ \text { UHPLC-QToF-MS } & \text { ultra high performance liquid chromatography-quadrupole Time-of-Flight-mass spectrometry } \\ \text { USFDA } & \text { United States food and Drug Administration }\end{array}$

\section{References}

1. Asowata-Ayodele, A.M.; Afolayan, A.J.; Otunola, G.A. Ethnobotanical survey of culinary herbs and spices used in the traditional medicinal system of Nkonkobe Municipality, Eastern Cape, South Africa. S. Afr. J. Bot. 2016, 104, 69-75. [CrossRef]

2. Vallverdú-Queralt, A.; Regueiro, J.; Martínez-Huélamo, M.; Rinaldi Alvarenga, J.F.; Leal, L.N.; Lamuela-Raventos, R.M. A comprehensive study on the phenolic profile of widely used culinary herbs and spices: Rosemary, thyme, oregano, cinnamon, cumin and bay. Food Chem. 2014, 154, 299-307. [CrossRef]

3. Weerakkody, N.S.; Caffin, N.; Turner, M.S.; Dykes, G.A. In vitro antimicrobial activity of less-utilized spice and herb extracts against selected food-borne bacteria. Food Control 2010, 21, 1408-1414. [CrossRef]

4. Ariaee, N.; Vahedi, Z.; Vahedi, F. Inhibitory effects of cinnamon-water extract on human tumor cell lines. Asian Pac. J. Trop. Dis. 2014, 4, S975-S978. [CrossRef] 
5. Embuscado, M.E. Spices and herbs: Natural sources of antioxidants-A mini review. J. Funct. Food 2015, 18, 811-819. [CrossRef]

6. Shan, B.; Cai, Y.Z.; Sun, M.; Corke, H. Antioxidant capacity of 26 spice extracts and characterization of their phenolic constituents. J. Agric. Food Chem. 2005, 53, 7749-7759. [CrossRef]

7. Shan, B.; Cai, Y.; Brooks, J.D.; Corke, H. The in vitro antibacterial activity of dietary spice and medicinal herb extracts. Int. J. Food Microbiol. 2007, 117, 112-119. [CrossRef]

8. Oonmetta-aree, J.; Suzuki, T.; Gasaluck, P.; Eumkeb, G. Antimicrobial properties and action of galangal (Alpinia galangal Linn.) on Staphylococcus aureus. LTW Food Sci. Technol. 2006, 39, 1214-1220. [CrossRef]

9. Kong, W.; Wei, R.; Logrieco, A.I.; Wei, J.; Wen, J.; Xiao, X.; Yang, M. Occurrence of toxigenic fungi and determination of mycotoxins by HPLC-FLD in functional foods and spices in China markets. Food Chem. 2014, 146, 320-326. [CrossRef] [PubMed]

10. Kaefer, M.C.; Milner, J.A. The role of herbs and spices in cancer prevention. J. Nutr. Biochem. 2008, 19, 347-361. [CrossRef] [PubMed]

11. Low Dog, T. A reason to season: The therapeutic benefits of spices and culinary herbs. Explore 2006, 2, 446-449. [CrossRef]

12. Karadas, C.; Kara, D. Chemometric approach to evaluate trace metal concentrations in some spices and herbs. Food Chem. 2012, 130, 196-202. [CrossRef]

13. Gonzalez, J.E.; Keshavan, N.D. Messing with bacterial quorum sensing. Microbiol. Mol. Biol. Rev. 2006, 70, 859-875. [CrossRef]

14. Keshavan, N.D.; Chowdary, P.K.; Haines, D.C.; Gonzalez, J.E. L-canavanine made by Medicago sativa interferes with quorum sensing in Sinorhizobium meliloti. J. Bacteriol. 2005, 187, 8427-8436. [CrossRef]

15. Truchado, P.; López-Gálvez, F.; Gil, M.I.; Tomás-Barberán, F.A.; Allende, A. Quorum sensing inhibitory and antimicrobial activities of honeys and the relationship with individual phenolics. Food Chem. 2009, 115, 1337-1344. [CrossRef]

16. Kasote, D.; Ahmad, A.; Chen, W.; Combrinck, S.; Viljoen, A. HPTLC-MS as an efficient hyphenated technique for the rapid identification of antimicrobial compounds from propolis. Phytochem. Lett. 2015, 11, 326-331. [CrossRef]

17. Nalina, T.; Rahim, A. The crude extract of Piper betel L. and its antibacterial effect towards Streptococcus mutans. Am. J. Biochem. Biotechnol. 2007, 3, 10-15.

18. Ng, W.L.; Perez, L.; Cong, J.; Semmelhack, M.F.; Bassler, B.L. Broad spectrum pro-quorum-sensing molecules as inhibitors of virulence in Vibrios. PLoS Pathog. 2012, 8, e1002767. [CrossRef]

19. Issac Abraham, S.V.P.; Palani, A.; Ramaswamy, B.R.; Shunmugiah, K.P.; Arumgam, V.R. Anti-quorum sensing and anti-biofilm potential of Capparis spinosa. Arch. Med. Res. 2011, 42, 658-668. [CrossRef] [PubMed]

20. Koh, C.L.; Sam, C.K.; Yin, W.F.; Tan, L.Y.; Krishnan, T.; Chong, Y.M.; Chan, K. Plant-derived natural products as sources of anti-quorum sensing compounds. Sensors 2013, 13, 6217-6228. [CrossRef]

21. Vasavi, H.S.; Arun, A.B.; Rekha, P.D. Anti-quorum sensing activity of flavonoid-rich fraction from Centella asiatica L. against Pseudomonas aeruginosa PAO1. J. Microbiol. Immunol. Inf. 2016, 49, 8-15. [CrossRef]

22. Fenwick, G.R.; Hanley, A.B. The genus Allium. Part 2. Crit. Rev. Food Sci. Nutr. 1985, 22, $273-377$.

23. Abu-Lafi, S.; Dembitsky, J.W.; Goldshlag, P.; Hanus, L.; Dembitsky, V.M. The use of the 'Cryogenic' GC-MS and on-column injection for study of organosulfur compounds of the Allium sativum. J. Food Compos. Anal. 2004, 17, 235-245. [CrossRef]

24. Jorge, V.G.; Ángel, J.R.; Adrián, T.S.; Francisco, A.C.; Anuar, S.G.; Samuel, E.S.; Ángel, S.O.; Emmanuel, H.N. Vasorelaxant activity of extracts obtained from Apium graveolens: Possible source for vasorelaxant molecules isolation with potential antihypertensive effect. Asian Pac. J. Trop. Biomed. 2013, 3, 776-779. [CrossRef]

25. Hussain, I.M.T.; Ahmed, G.; Jahan, N.; Adiba, M. Unani description of Tukhme Karafs (seeds of Apium graveolens Linn) and its scientific reports. Int. Res. J. Biol. Sci. 2013, 2, 88-93.

26. Bladh, W.K.; Olsson, K.M. Introduction and use of horseradish (Armoracia rusticana) as food and medicine from antiquity to the present: Emphasis on the Nordic countries. J. Herbs Spices Med. Plants 2011, 17, 197-213. [CrossRef]

27. Tolan, I.; Ragoobirsingh, D.; Morrison, E.Y. Isolation and purification of the hypoglycaemic principle present in Capsicum frutescens. Phytother. Res. 2004, 18, 95-96. [CrossRef] 
28. Tundis, R.; Federica, M.; Marco, B.; Filomena, C.; Giancarlo, S.; Francesco, M.; Loizzo, M. Antioxidant and hypoglycaemic activities and their relationship to phytochemicals in Capsicum annuum cultivars during fruit development. LWT Food Sci. Technol. 2013, 53, 370-377. [CrossRef]

29. Labban, L. Medicinal and pharmacological properties of turmeric (Curcuma longa): A review. Int. J. Pharm. Biomed. Sci. 2014, 5, 17-23.

30. Chandrasekaran, C.V.; Deepak, H.B.; Thiyagarajan, P.; Kathiresan, S.; Sangli, G.K.; Deepak, M.; Amit, A. Dual inhibitory effect of Glycyrrhiza glabra (GutGard ${ }^{\mathrm{TM}}$ ) on COX and LOX products. Phytomedicine 2011, 18, 278-284. [CrossRef]

31. Weitzel, C.; Petersen, M. Cloning and characterisation of rosmarinic acid synthase from Melissa officinalis L. Phytochemistry 2011, 72, 572-578. [CrossRef]

32. Paul, R.; Data, A.K. An updated overview on peppermint (Mentha piperita L.). Int. Res. J. Pharm. 2011, 2, $1-10$.

33. Ventura-Martinez, R.; Rivero-Osorno, O.; Gomez, C.; González-Trujano, E.M. Spasmolytic activity of Rosmarinus officinalis L. involves calcium channels in the guinea pig ileum. J. Ethnopharmacol. 2011, 137, 528-532. [CrossRef]

34. Hossain, M.A.; Harbi, S.R.A.; Weli, A.M.; Al-Riyami, Q.; Al-Sabahi, J. Comparison of chemical constituents and antimicrobial activities of three essential oils from three different brands' clove samples collected from Gulf region. Asian Pac. J. Trop. Dis. 2014, 4, 262-268. [CrossRef]

35. Dragland, S.; Senoo, H.; Wake, K. Several culinary and medicinal herbs are important sources of dietary antioxidants. J. Nutr. 2003, 133, 1286-1290. [CrossRef]

36. Alqareer, A.; Alyahya, A.; Andersson, L. The effect of clove and benzocaine versus placebo as topical anesthetics. J. Dent. 2006, 34, 747-750. [CrossRef]

37. Kozics, K.; Klusová, V.; Srančíková, A.; Mučaji, P.; Slameňová, D.; Hunáková, L.; Horváthová, E. Effects of Salvia officinalis and Thymus vulgaris on oxidant induced DNA damage and antioxidant status in HepG2 cells. Food Chem. 2013, 141, 2198-2206. [CrossRef]

38. Karuppiah, P.; Rajaram, S. Antibacterial effect of Allium sativum cloves and Zingiber officinale rhizomes against multiple-drug resistant clinical pathogens. Asian Pac. J. Trop. Biomed. 2012, 2, 597-601. [CrossRef]

39. Khan, M.S.; Zahin, M.; Hasan, S.; Husain, F.M.; Ahmad, I. Inhibition of quorum sensing regulated bacterial functions by plant essential oils with special reference to clove oil. Lett. Appl. Microbiol. 2009, 49, 354-360. [CrossRef]

40. Clinical and Laboratory Standards Institute (CLSI). Performance Standards for Antimicrobial Susceptibility Testing; CLSI: Wayne, PA, USA, 2007; Volume 27.

41. EUCAST (European Committee for Antimicrobial Susceptibility Testing). Determination of minimum inhibitory concentrations (MICs) of antibacterial agents by broth dilution. Eur. J. Clin. Microbiol. Infect. Dis. 2003, 9, 1-7.

42. Eloff, J.N. A sensitive and quick microplate method to determine the minimal inhibitory concentration of plant extracts for bacteria. Planta Med. 1998, 64, 711-713. [CrossRef]

43. McLean, R.J.; Pierson, L.S.; Fuqua, C. A simple screening protocol for the identification of quorum signal antagonists. J. Microbiol. Methods 2004, 58, 351-360. [CrossRef]

44. McClean, K.H.; Winson, M.K.; Fish, L.; Taylor, A.; Chhabra, S.R.; Camara, M.; Daykin, M.; Lamb, J.H.; Swift, S.; Bycroft, B.W.; et al. Quorum sensing and Chromobacterium violaceum: Exploitation of violacein production and inhibition for the detection of N-acylhomoserine lactones. Microbiology 1997, 143, 3703-3711. [CrossRef] [PubMed]

45. Alkuraishy, H.M. Evaluation the antibacterial activity of aniseed: In vitro study. J. Clin. Res. Healthc. Man 2012, 3, 1-7.

46. Alzoreky, N.S.; Nakahara, K. Antibacterial activity of extracts from some edible plants commonly consumed in Asia. Int. J. Food Microbiol. 2003, 80, 223-230. [CrossRef]

47. Van Vuuren, S.F. Antimicrobial activity of South African medicinal plants. J. Ethnopharmacol. 2008, 119, 462-472. [CrossRef]

48. Packiavathy, I.A.S.V.; Agilandeswari, P.; Musthafa, K.S.; Pandian, S.K.; Ravi, A.V. Antibiofilm and quorum sensing inhibitory potential of Cuminum cyminum and its secondary metabolite methyl eugenol against Gram negative bacterial pathogens. Food Res. Int. 2012, 45, 85-92. [CrossRef] 
49. Chenia, H.Y. Anti-quorum sensing potential of crude Kigelia africana fruit extracts. Sensors 2013, 13, $2802-2817$. [CrossRef] [PubMed]

50. Dong, Y.; Zhao, M.; Zhao, T.; Feng, M.; Chen, H.; Zhuang, M.; Lin, L. Bioactive profiles, antioxidant activities, nitrite scavenging capacities and protective effects on h2o2-injured pc12 cells of Glycyrrhiza glabra L. leaf and root extracts. Molecules 2014, 19, 9101-9113. [CrossRef]

51. Dong, Y.H.; Zhang, L.H. Quorum sensing and quorum-quenching enzymes. J. Microbiol. 2005, 43, 101-109. [PubMed]

52. Jakobsen, T.M.; van Gennip, M.; Phipps, R.K.; Shanmugham, M.S.; Christensen, L.D.; Alhede, M.; Skinersoe, M.E.; Rasmussen, T.B.; Friedrich, K.; Uthe, F.; et al. Ajoene, a sulphur-rich molecule from garlic, inhibits genes controlled by quorum sensing. Antimicrob. Agents Chemother. 2012, 56, 2314-2325. [CrossRef]

53. Choo, J.H.; Rukayadi, Y.; Hwang, J.K. Inhibition of bacterial quorum sensing by vanilla extract. Lett. Appl. Microbiol. 2006, 42, 637-641. [CrossRef]

54. Vattem, D.A.; Mihalik, K.; Crixell, S.H.; McLean, R.J. Dietary phytochemicals as quorum sensing inhibitors. Fitoterapia 2007, 78, 302-310. [CrossRef]

55. Krishnan, T.; Yin, W.F.; Chan, K.G. Inhibition of quorum sensing-controlled virulence factor production in Pseudomonas aeruginosa PAO1 by ayurveda spice clove (Syzygium aromaticum) bud extract. Sensors 2012, 12, 4016-4030. [CrossRef]

56. Adonizio, A.L.; Downum, K.; Bennett, B.C.; Mathee, K. Anti-quorum sensing activity of medicinal plants in southern Florida. J. Ethnopharmacol. 2006, 105, 427-435. [CrossRef]

57. Tang, J.; Zhang, Y.; Hartman, T.G.; Rosen, R.T.; Ho, C.T. Free and glycosidically bound volatile compounds in fresh celery (Apium graveolens L.). J. Agric. Food Chem. 1990, 38, 1937-1940. [CrossRef]

58. Ahluwalia, V.K.; Boyda, D.R.; Jain, A.K.; Khanduri, C.H.; Sharma, N.D. Furanocoumarin glucosides from the seeds of Apium graveolens. Phytochemistry 1988, 27, 1181-1183. [CrossRef]

59. Kurobayashi, Y.; Kouno, E.; Fujita, A.; Morimitsu, Y.; Kubota, K. Potent odorants characterize the aroma quality of leaves and stalks in raw and boiled celery. Biosci. Biotechnol. Biochem. 2006, 70, 958-965. [CrossRef]

60. Mihalik, K.; Chung, D.W.; Crixell, S.H.; McLean, R.J.C.; Vattem, D.A. Quorum sensing modulators of Pseudomonas aeruginosa characterized in Camellia sinensis. Asian J. Tradit. Med. 2008, 3, 12-23.

61. Givskov, M.; de Nys, R.; Manefield, M.; Gram, L.; Maximilien, R.; Eberl, L.; Molin, S.; Steinberg, P.D.; Kjelleberg, S. Eukaryotic interference with homoserine lactone-mediated prokaryotic signalling. J. Bacteriol. 1996, 178, 6618-6622. [CrossRef]

62. Manefield, M.; de Nys, R.; Kumar, N.; Read, R.; Givskov, M.; Steinberg, P.; Kjelleberg, S. Evidence that halogenated furanones from Delisea pulchra inhibit acylated homoserine lactone (AHL)-mediated gene expression by displacing the AHL signal from its receptor protein. Microbiology 1999, 145, 283-291. [CrossRef] 